\title{
PENDAMPINGAN DAN PEMBINAAN KOMUNITAS MUALLAF MELALUI PEMBIBITAN PERANGKAT SYARA' DI DESA WAMANA BARU KEC. FENA LEISELA KAB. BURU, MALUKU
}

\author{
Andi Fitriyani)*, Baiti Renel, Darma, Subair \\ Institut Agama Islam Negeri Ambon \\ *) E-mail: andifitryani@gmail.com
}

\begin{abstract}
This paper is a critical effort made to respond to the reality of what happened in Maluku related to the widespread development of capitalism. With reviews that uses narrative approach, then this article seeks to present issues related to the influence of capitalism and the hegemonic power (governmental) on the Maluku people who have an impact on the welfare and comfort of their lives, a small community. It must be recognized that this writing is still far from eligibility as a good writing. However, with the existing shortcomings we try to explain it, assisted by the use of the theory of the takeover secretly (the silent take over), Hertz and hegemony (Gramsci), so this article can explain about problems multiulturalisme as teriadi in Maluku.
\end{abstract}

Keywords: Capitalism, Hegemony of Power, Multiculturalism, Small Community Rights

\section{ABSTRAK}

Dakwah pada level desa biasanya secara dimotori oleh para imam dan takmir masjid yang secara struktural dipilih secara langsung oleh umat dan biasanya disebut dengan Perangkat Syara'. Perangkat Syara' inilah sesungguhnya pelaksana lapangan yang setiap saat bersinggungan dengan umat. Karena itu, wajah kemajuan keberagamaan umat di level desa sangat tergantung sejauhmana kualitas personal dan manajerial para Pegawai Syara' tersebut. Mengingat eksistensi Perangkat Syara' yang demikian urgennya maka meningkatkan kualitas baik secara personal maupun manajerial mereka sama halnya dengan peningkatan kualitas kehidupan keagamaan di tengah masyarakat di desa. Pembibitan perangkat syara' menjadi semakin penting mengingat persoalan muallaf di Wamana Baru tidak hanya sebatas masalah aqidah, ibadah dan muamalah belaka juga terkait dengan masalah kelembagaan yakni tidak adanya perangkat syara' yang melayani dan memenuhi kebutuhan masyarakat muallaf. Sebagai akibatnya, beberapa ibadah dan amalan pokok seperti shalat Jumat, penyelenggaraan jenazah hingga kepada pendidikan Islam tidak pernah dilaksanakan di Desa Wamana Baru. Program pendampingan dan pembinaan muallaf di Desa Wamana Baru dilakukan melalui empat kegiatan yakni pembinaan Aqidah, Pendidikan dan Pelatihan dasar-dasar ibadah Islam, Pendidikan dan Pelatihan Guru TPQ, dan Pembentukan dan Pembinaan Majelis Taklim. Pada dasarnya seluruh kegiatan dimaksudkan sebagai program pembibitan Perangkat Syara' sebagai cikal bakal pembentukan Perangkat Syara' yang nantinya akan melayani kebutuhan masyarakat muslim terkait masalah keagamaannya.

Kata kunci: Pendampingan, Pembinaan, Muallaf, Perangkat Syara'

\section{PENDAHULUAN}

Komunitas Muallaf di Desa Wamana Baru merupakan bagian dari Suku Buru, penduduk asli Pulau Buru. Pulau Buru ini terletak di Kepulauan Maluku dan merupakan salah satu yang terbesar di sana. Suku Buru sebagian besar masih mempertahankan agama kepercayaan tradisional, yaitu masih memuja benda-benda dan roh-roh (animisme dan dinamisme). Mereka melakukan pemujaan terhadap dewa tertingginya, Opo Hebe Snulat dan utusan-Nya, Nabiat. Selain itu, mereka juga percaya akan adanya roh abadi yang disebut esmangin, roh alam yang disebut sanane, roh orang mati yang disebut nituro, dan sebagainya. Kepercayaan terhadap kekuatan-kekuatan gaib ini diwujudkan dengan pemberian sesaji dan upacara pada waktu-waktu tertentu.

Sejak tahun 1990-an, Islam mulai menjadi salah satu agama Wamana Baru setelah seorang pedagang muslim sering mendatangi desa itu untuk menjajakan dagangannya. Perlu diketahui bahwa penduduk Pulau Buru, terutama yang berdiam di sekitar pantai, umumnya memeluk agama Islam. Hal ini berkaitan dengan pengaruh Kesultanan Ternate yang menjadi pusat penyebaran Islam di daerah Maluku. Saat ini penduduk Muslim menempati urutan kedua jumlah terbesar setelah penduduk yang beragama Hindu animisme/dinamisme). Jumlah penduduk muslim adalah sekitar 137 orang yang terdiri atas 14 kepala keluarga. Sejak proses 
pengislaman terjadi, belum ada pembinaan muallaf yang konsisten dilakukan kepada Muallaf di desa ini. Keberislaman penduduk bercampur baur dengan praktek agama lama dan bahkan lebih dominan agama lama dalam kepercayaan dan prakteknya. Berdasarkan hasil penelitian pendahuluan, salah satu masalah terbesar dari komunita muallaf di desa Wamana Baru adalah tidak adanya perangkat syara'. Sebagai akibatnya, kebutuhan hidup beragama seperti Imam dan Khatib Shalat Jumat, Guru Mengaji dan pelaksana seremonial keagamaan lainnya belum ada. Selama ini mereka bergantung kepada perangkat syara' dari desa muslim tetangganya.

Pembinaan keberagamaan difokuskan pada 'pembibitan' perangkat syara' karena berdasarkan hasil observasi pendahuluan dan hasil diskusi bersama tim Pesantren Al-Anshor ternyata kebutuhan hidup beragama seperti Imam dan Khatib Shalat Jumat, Guru Mengaji dan pelaksana seremonial keagamaan lainnya belum ada. Selama ini mereka bergantung kepada perangkat syara' dari desa muslim tetangganya. Dakwah pada level desa biasanya secara dimotori oleh para imam dan takmir masjid yang secara struktural dipilih secara langsung oleh umat dan biasanya disebut dengan Pegawai Syara'. Pegawai Syara' inilah sesungguhnya pelaksana lapangan yang setiap saat bersinggungan dengan umat. Karena itu, wajah kemajuan keberagamaan umat di level desa dan kelurahan sangat tergantung sejauhmana kualitas personal dan manajerial para Pegawai Syara' tersebut.

Dakwah pada level desa biasanya secara dimotori oleh para imam dan takmir masjid yang secara struktural dipilih secara langsung oleh umat dan biasanya disebut dengan Perangkat Syara'. Perangkat Syara' inilah sesungguhnya pelaksana lapangan yang setiap saat bersinggungan dengan umat. Karena itu, wajah kemajuan keberagamaan umat di level desa sangat tergantung sejauhmana kualitas personal dan manajerial para Pegawai Syara' tersebut. Mengingat eksistensi Perangkat Syara' yang demikian urgennya maka meningkatkan kualitas baik secara personal maupun manajerial mereka sama halnya dengan peningkatan kualitas kehidupan keagamaan di tengah masyarakat di desa. Kemampuan personal yang harus dimiliki Perangkat Syara' meliputi pengetahuan keagamaan, sosial, dan budaya. Sementara penguasaan manajerial meliputi bagaimana cara mengelola dan memanfaatkan sinergis potensi yang ada di tengah masyarakat untuk digunakan secara optimal bagi pelaksanaan dakwah secara lebih luas sehingga tercipta suasana masyarakat yang tumbuh dan berkembang dalam nilai-nilai dan tatanan masyarakat Islam.

\section{METODOLOGI}

Program pengabdian masyarakat ini merupakan riset aksi yang merupakan bagian dari pendekatan kualitatif (Denzin, \& Lincoln (eds.), 2000). Menurut Gilmore dkk. (1986: 161), riset aksi ditujukan memberikan konstribusi praktis: penyelesaian masalah masyarakat jangka pendek dan tujuan jangka panjang ilmu sosial dan perubahan sosial sekaligus. Jadi ada dua komitmen: mempelajari sistem, dan bersamaan dengan itu membangun kerjasama di antara orang-orang yang ada didalamnya untuk merubahnya. Untuk mencapai dua tujuan ini mensyarakatkan kerjasama aktif antara researcher (dari luar) dan anggota organisasi/masyarakat, dengan menekankan pada proses belajar sebagai aspek dasar proses riset.

Pemberdayaan Muallaf di Wamana Baru dilakukan melalui beberapa tahapan program yang dirancang secara siklis sebagai proses yang berkesinambungan. Tahap pertama adalah program pembinaan. Pembinaan mualaf memiliki peran penting dalam meningkatkan keimanan mereka. Selama ini, program pembinaan bagi para mualaf masih belum terstruktur. Saat ini pendekatan pembinaan mualaf juga belum menggunakan pendekatan spiritual ataupun intelektual. Mestinya, pembinaan terhadap mualaf dilakukan melalui pendekatan yang lebih lengkap. Oleh karena itu, pembinaan Muallaf yang utama dan pertama yang akan dilakukan adalah berkaitan dengan sisi spiritual/aqidah dan intelektual. Berdasarkan pengalaman Rasulullah ketika mensyiarkan agama Islam, Rasulullah berdakwah kepada ummatnya didahului dengan penguatan keimanan dan moral selama lebih dari 10 tahun, ketika itu belum ada perintah shalat, zakat, juga puasa, apalagi haji. Setelah itu baru dilakukan pembinaan ibadah atau fiqh.

\section{PROFIL MUALLAF DI DESA WAMANA BARU}

Desa Wamana Baru berada dalam wilayah administrasi Kecamatan Fena Leisela merupakan daerah pusat pemerintahan adat Regenscaf/Petuanan Leisela yang membentang dari kali Waeikan (Kab.Bursel) sampai Kali Waemasi, dengan kode wilayah 81.04.13. Luas wilayahnya $2.831,65 \mathrm{~km} 2$, diresmikan melalui Peraturan Daerah Kabupaten Buru Nomor 22 Tahun 2012 tentang Pemekaran Kecamatan Fena Leisela. Kecamatan ini sendiri 
merupakan pemekaran dari Kecamatan Air Buaya, dengan ibukota kecamatan pada Desa Wamlana, terdiri dari 13 (tiga belas) desa, yakni : 1. Desa Wamlana, 2. Desa Balbalu, 3. Desa Waspait, 4. Desa Waenibe, 5. Desa Waedanga, 6. Desa Lemanpoli, 7. Desa Waelana lana, 8. Desa Waereman, 9. Desa Waemite, 10. Desa Wasi, 11. Desa Waekose, 12. Desa Wamana Baru, 13. Desa Raheriat.

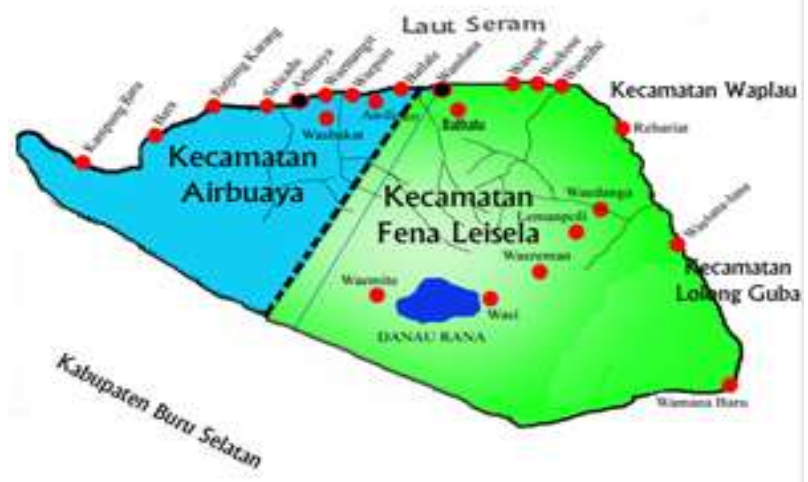

Gambar 4.2. Peta Kecamatan Fena Leisela

Desa Wamana Baru pertama kali dibuka pada tahun 1989 dengan nama kampung Wamana Baru, sebelumnya itu masyarakat masih mendiami di Walalikan yang didominasi oleh penduduk asli Danau Rana atau marga Waekolo. Namun sulit dijangkau ke pasar atau daerah sentral ekonomi maka pada tahun 1989 atas kepimipinan Bapak Kawasan Mana Wael beliau melakukan pertemuan dengan masyarakat setempat dalam pertemuan itu beliau mengusulkan untuk berpidah tempat tinggal ke tempat yang lebih dekat atau mudah di jangkauan ke pasar atau sentral ekonomi yang lebih dekat dengan demikian usulan tersebut disepakati masyarakat.

Penduduk Desa Wamana Baru pada tahun 2016 berjumlah 1,434 orang. Komposisi penduduk dapat dilihat pada Tabel 1.

Tabel 1. Komposisi Penduduk Desa Wamana Baru berdasarkan Usia Tahun 2016

\begin{tabular}{|c|l|c|c|c|}
\hline NO & URAIAN & L & P & JUMLAH \\
\hline 1 & $\begin{array}{l}\text { Jumlah } \\
\text { Dandudul }\end{array}$ & 635 & 748 & 1,434 Jiwa \\
\hline 2 & Jumlah KK & & & 280 \\
\hline 3 & Jumlah & & & \\
\hline 4 & a. $0-$ 5 tahun & 66 & 74 & 140 \\
\hline 5 & b. $6-10$ tahun & 85 & 95 & 180 \\
\hline 6 & c. $11-15$ & 103 & 96 & 199 \\
\hline 7 & d. $16-20$ & 49 & 42 & 91 \\
\hline
\end{tabular}

\begin{tabular}{|l|l|l|c|c|}
\hline 8 & e. $21-25$ tahun & 71 & 60 & 131 \\
\hline 9 & f. $26-30$ tahun & 49 & 44 & 93 \\
\hline 10 & g. $31-35$ & 66 & 59 & 125 \\
\hline 11 & h. $36-40$ tahun & 69 & 63 & 132 \\
\hline 12 & i. $41-45$ tabun & 63 & 65 & 128 \\
\hline 13 & j. $46-50$ tahun & 59 & 57 & 116 \\
\hline 14 & k. 50 tahun ke & 46 & 53 & 99 \\
\hline \multicolumn{2}{|c|}{ Jumlah Total } & & & 1,434 \\
\hline
\end{tabular}

Sumber: Data Monograf Desa Wamana Baru

Pada tabel 1 terlihat bahwa komposisi penduduk Desa Wamana Baru didominasi oleh penduduk usia muda yang belum produktif. Data tersebut menunjukkan bahwa terjadi tingkat pertumbuhan penduduk yang cukup tinggi dan data seperti itu berpotensi menjadi masalah apabila usia muda yang seharusnya bersekolah tidak terserap dalam lembaga-lembaga pendidikan dasar. Untuk melihat tingkat pendidikan masyarakat Wamana Baru, disajikan pada tabel 2

Tabel 2. Komposisi Penduduk Desa Wamana Baru menurut Tingkat Pendidikan Tahun 2016

\begin{tabular}{|l|c|c|}
\hline \multicolumn{1}{|c|}{ Tingkat Pendidikan } & $\mathrm{L}$ & $\mathrm{P}$ \\
\hline Usia 3-6 tahun yang belum masuk. & 73 & 67 \\
\hline Usia 3-6 tahun yang sedang TK & - & - \\
\hline Usia 7-18 tahun yang tidak pernah & 260 & 233 \\
\hline Usia 7-18 tahun yang sedang & 120 & 111 \\
\hline Usia 18-56 tahun yang tidak pernah & 115 & 95 \\
\hline Usia 18-56 tahun yang tidak tamat & 22 & 170 \\
\hline Usia 18-56 tahun yang tidak tamat & 27 & 16 \\
\hline Usia 18-56 tahun yang tidak tamat & 18 & 23 \\
\hline Tamat SD/Sederajat & 75 & 87 \\
\hline Tamat SMP/Sederaiat & 24 & 18 \\
\hline Tamat SMAlSederajat & 14 & 16 \\
\hline Tamat D-2/Sederajat & - & - \\
\hline Tamat D-3/Sederajat & 1 & - \\
\hline Tamat S-IISederaiat & 1 & 3 \\
\hline Jumlah Total & 14340 \\
\hline
\end{tabular}

Sumber: Data Monograf Desa Wamana Baru

Mata pencaharian pokok orang penduduk Wamana Baru adalah mengumpulkan dan meramu sagu hutan, yang menjadi makanan pokok mereka. Sebagaimana suku asli Buru lainnya, penduduk desa ini sangat dekat dengan tanah dalam artian bahwa mata pencariannya adalah bertani dan berladang, mereka juga termasuk pemburu ulung dengan menggunakan senjata tradisional berupa parang lurus dan tombak pendek. Suku bangsa buru asli 
adalah suku bangsa yang tipikal dari suku bangsa yang sangat mengendalikan pengolahan lahan bumi sebagai sumber kehidupannya. Desa ini terkenal sebagai penghasil minyak kayu putih di mana sebagian besar lahannya ditumbuhi pohon kayu putih secara alami. Mata pencaharian penduduk Wamana Baru dapat dilihat pada tabel 3.

Tabel 3. Komposisi Penduduk Desa Wamana Baru menurut Mata Pencaharian Penduduk Desa Tahun 2016

\begin{tabular}{|l|c|c|}
\hline \multicolumn{1}{|c|}{ Jenis Pekerjaan } & L & P \\
\hline Pegawai Negeri Sipil (PNS) & 5 & 2 \\
\hline TNI dan POLRI & 1 & - \\
\hline Bidan & 1 & - \\
\hline Guru TK, SD, SMP dan SMA & 4 & 3 \\
\hline Petani / Peternak & 26 & 95 \\
\hline Pedagang & - & \\
\hline Buruh Bangunan & 6 & - \\
\hline Tukang Batu & 3 & 2 \\
\hline Buruh tani & 19 & 12 \\
\hline Sopir & 9 & - \\
\hline Tukang Ojek & - & - \\
\hline Belum Bekerja & 31 & 25 \\
\hline Lain-lain & - & - \\
\hline Suber Data Mogra Desa Wand
\end{tabular}

Sumber: Data Monograf Desa Wamana Baru

Sebagai bagian dari masyarakat Adat Buru, agama awal dari masyarakat Wamana Baru adalah agama Adat (Alifuru). Dalam KTP-nya, agama tersebut dikonversi ke agama Hindu. Konversi tersebut menimbulkan masalah yang cukup serius karena menurut Kepala Kantor Kementerian Agama Kabupaten Buru, agama Adat dan agama Hindu tidaklah sama sama sekali. Ada yang menyebutnya dengan Hindu Tanah, itu kata Kepala Kantor juga tidak lah sama. Agama Adat adalah animisme yang masih merupakan agama asli penduduk yang tinggal di pedalaman Pulau Buru. Komposisi penduduk Wamana Baru berdasar agama yang dianut disajikan pada tabel 4.

Tabel. 4. Komposisi penduduk Desa Wamana Baru menurut Agama dan Kepercayaan kepada Tuhan Yang Maha Esa

\begin{tabular}{|r|l|c|c|}
\hline No & \multicolumn{1}{|c|}{ Agama } & L & P \\
\hline 1 & Islam & 89 & 48 \\
\hline 2 & Kristen protestan & 32 & 28 \\
\hline 3 & Katholik & - & - \\
\hline 4 & Hindu & 628 & 609 \\
\hline
\end{tabular}

\begin{tabular}{|r|l|c|c|}
\hline 5 & Budha & - & - \\
\hline 6 & Khonghucu & - & - \\
\hline 7 & Kepercayaan Kepada Tuhan & - & - \\
\hline 8 & Aliran Kepercayaan Lainnya & - & - \\
\hline & Jumlah & 749 & 685 \\
\hline & Total & \multicolumn{2}{|c|}{1.434} \\
\hline
\end{tabular}

Sumber: Data Monograf Desa Wamana Baru

Pada tabel 4 terlihat bahwa terdapat tiga agama di desa Wamana Baru dengan agama Hindu sebagai agama mayoritas. Masyarakat menyebut agama mereka sebagai agama adat. Sebagian masyarakat juga menyebutnya dengan agama gunung dan agama Alifuru. Sepertinya agama Hindu adalah agama yang terdekat berdasarkan karakteristiknya sehingga dalam formalisasi agama warga negara mereka dimasukkan ke dalam agama Hindu. Dalam tulisannya, "Tribal religions di Indonesia", Waldemar Stohr, menjelaskan bahwa suatu kelompok etnik tidak saja dapat dipahami sebagai atau diidentifikasi sebagai suatu kelompok manusia yang memikirkan tentang mereka sendiri sebagaimana mereka ada, di mana ada kebudayaan, bahasa, keturunan. Lebih dari itu, suatu kelompok etnik adalah suatu jaringan, dari ikatan atau interelasi kehidupan, interelasi atau jaringanjaringan yang meliputi dewa-dewa, spirit atau roh, tanah dan fenomena-fenomena lain dari lingkungannya.

\section{PROGRAM PENDAMPINGAN DAN PEMBINAAN MUALLAF}

Program pendampingan dan pembinaan muallaf di Desa Wamana Baru dilakukan melalui 4 kegiatan yakni pertama Pembinaan Aqidah muallaf melalui ceramah tentang aqidah Islam. Kedua Pendidikan dan Pelatihan dasar-dasar ibadah Islam yakni tharah (berwudhu dan mandi junub), shalat wajib dan penyelenggaraan jenazah. Ketiga Pendidikan dan Pelatihan Guru TPQ. Keempat, Pembentukan dan Pembinaan Majelis Taklim Ibuibu dan remaja putri. Keempat agenda tersebut bertambah menjadi 5 kegiatan dengan dilakukannnya pembinaan Calon Perangkat Syara' karena ternyata belum ada perangkat syara' sama sekali di Desa Wamana Baru.

Kepala Desa dan Sekretaris Desa Wamana Baru beragama Hindu, begitu pula dengan seluruh kepala Soa, Tampaknya jabatan adat membuat pejabat desa itu mempertahankan agamanya. Sebagai contoh, Sekretaris Desa yang masih 
beragama Hindu justru menyuruh semua anaknya menjadi muallaf. Salah seorang anak perempuannya bahkan sudah dititip untuk dididik di Pondok Pesantren Al-Anshor Ambon dan ikut bersama tim dari Ambon ke Wamana Baru. Bagi Sekretaris Desa, perbedaan agama bukanlah masalah karena bagi mereka, adat adalah yang paling utama. Agama bisa berbeda tetapi keluarga tetap satu. Sehingga tidak heran, banyak keluarga di Wamana Baru yang terdiri dari dua atau tiga agama dalam 1 rumah.

“...sehingga tidak ada masalah kalau dalam satu rumah terdiri atas berbagai macam agama. Keluarga di atas segala-galanya. Beda agama baru. Agama nenek moyang dulu agama adat. Islam lebih dulu masuk ke Wamana Baru daripada Kristen. Kristen masuk sekitar tahun 1988. Islam jauh sebelum itu. Katong ini walaupun berbeda agama tetapi katong pung bapak soa ini kuat".

\section{Pembinaan Aqidah Muallaf}

Pembinaan aqidah muallaf hari pertama dilakukan setelah acara pembukaan bertempat di Masjid Nurul Iman, mulai jam 14.00. Acara dimulai dengan sambutan dari Kepala Kantor Kementerian Agama Kabupaten Buru, Drs. M. Taslim Tuasikal. Rencana awalnya Kepala Kantor yang akan membuka kegiatan di pagi hari tetapi tidak bisa datang pagi karena mendadak ada kegiatan dengan Bupati Buru. Setelah berdiskusi dengan Dr. Subair dari IAIN Ambon, berjanji akan melayani masyarakat Wamana Baru secara langsung. Drs. Taslim Tuasikal menyampaikan bahwa Pemerintah Daerah Kabupaten Buru memiliki Peraturan Daerah Gerakan Masyarakat Bupolo Mengaji. Magrib dan Isya semua harus mengaji. Dalam rangka gerakan ini, setiap Taman Pengajian Qur'an (TPQ) diberi insentif Rp. 550.000 setiap bulan. Demikian pula untuk Imam Masjid. Oleh karenanya, Taslim meminta kepada Tim IAIN Ambon membantu masyarakat muallaf Desa Wamana Baru membentuk dan menyusun perangkat syara' dari Imam Desa, Modim sampai kepada Pengurus TPQ.

Dalam kesempatan itu Kepala Kantor Kementerian Agama Kabupaten Buru mengingatkan kepada pasangan suami isteri desa Wamana Baru yang beragama Islam yang belum memiliki buku nikah segera melapor pada KUA terdekat untuk selanjutnya dapat diproses hingga penerbitan buku nikah. Dirinya menambahkan pembinaan secara langsung kepada binaan seperti yang dilakukan LP2M IAIN Ambon dan Ponpes Al Ansor merupakan bukti kerja yang lebih mengutamakan pelayanan langsung.
Mengetahui bahwa Tim IAIN Ambon dan PP Al-Anshor akan melaksanakan juga pelatihan Guru TPQ, Kepala Kantor Kementerian Agama Kabupaten Buru menyambutnya dengan sangat baik. Dalam sambutannya Kepala Kantor menjelaskan bahwa Taman Pendidikan Al-Qur'an sangat berperan dalam mendidik dan melahirkan generasi muslim yang cinta dan mengamalkan ajaran Islam yang sesuai dengan syari'ahnya dan diimplementasikan dalam kehidupan bermasyarakat serta mampu menghadapi era globalisasi saat ini. Kepala Kantor berharap dengan diselenggarakannya kegiatan pembinaan ini bisa meningkatkan silaturahim dan tukar informasi tentang berbagai model dan sistem pengelolaan TPQ, Terbangunnya Komunikasi, Koordinasi yang intensif antar TPQ dengan satuan Pengelolaan Lembaga Pendidikan Keagamaan, Memberikan Pemahaman yang lebih baik tentang Program Pembinaan TPQ yang dilaksanakan oleh Kementerian Agama.

"Pemerintah Kabupaten Buru sangat menginginkan adanya kualitas dari tenaga pengajar TPQ. Untuk itu dengan adanya pelatihan dan pembinaan ini diharapkan akan menambah pengetahuan bagi para pengajar sehingga akan berdampak pada lahirnya anak-anak Bupolo yang Qur'ani serta memliki pengetahuan Islam sebagai bekal untuk mereka dewasa nanti".

Selanjutnya Kepala Kantor Kementerian Agama Kabupaten Buru mengatakan bahwa pengetahuan petugas imam dan khotib perlu ditingkatkan sehingga nantinya benar-benar mampu menjadi panutan masyarakat khususnya dalam melaksanakan ibadah sholat. Taslim menjelaskan pada dasarnya pembinaan yang dilakukan oleh Kementerian Agama kepada seluruh pemeluk agama bertujuan agar umat yang satu baik dengan umat yang lain sehingga kerukunan antar umat beragama tetap terjaga. Sinergitas Kementerian Agama dengan lembaga-lembaga keagamaan untuk pembangunan umat harus terus dilakukan agar kerukunan dan keharmonisan antar agama dapat tercapai.

Kepada Tim IAIN Ambon Kepala Kantor Kementerian Agama Kabupaten Buru meminta agar pembinaan yang dilakukan kepada muallaf jangan sampai membuat muallaf berpikir bahwa Islam itu agama yang susah untuk dilaksanakan. Dia memberi contoh bahwa banyak muallaf di Kabupaten buru yang murtad karena tidak adanya pembinaan atau karena langsung dikenalkan dengan hukum Islam yang keras dan bertentangan dengan adat yang sebelumnya sangat dijunjung tinggi. Dia menyebutkan bahwa tidak jarang muallf yang 
dikunjunginya mengatakan: "Katong (kami) seng (tidak) mau lai (lagi) di Islam karena ada yang bilang kalau katong di Islam katong pung (punya) adat-adat hilang." Islam harus disampaikan secara bertahap dengan pertama kali membina aqidah muallaf terlebih dahulu.

Dalam pembinaan muallaf yang utama dan pertama ditanamkan adalah berkaitan dengan aqidah, hal ini berdasarkan pengalaman Rasulullah ketika mensyiarkan agama Islam. Rasulullah berdakwah kepada ummatnya didahului dengan penguatan keimanan dan moral selama lebih dari 10 tahun, ketika itu belum ada perintah shalat, zakat, juga puasa, apalagi haji. Setelah itu baru dilakukan pembinaan ibadah atau fiqh. Dakwah harus dilakukan untuk tiga hal yaitu; mengenalkan Islam kepada yang bukan beragama Islam, menguatkan aqidah umat muslim, dan menjaga keutuhan NKRI.

Dalam melakukan pendampingan terhadap muallaf harus memperhatikan psikologis muallaf, karena permasalahan muallaf yang paling dirasakan adalah soal psikologis dalam keluarga dan lingkungan.

Selanjutnya pembinaan aqidah dilakukan secara intensif selama tim berada di Wamana Baru. Pengajian selalu dilakukan setelah pelaksanaan shalat Magrib dan Subuh selama 3 hari Tim dilokasi. Secara bergantian materi tausiyah diberikan oleh Ust. Abu Imam Rumbara, Ust. H. Ahmad Nurdin, S.Pd dan Dr. H. Subair, M.Si. Ust. Ust. H. Ahmad Nurdin adalah Kepala Sekolah MTs PP Al-Anshor yang sudah pernah berkunjung ke Desa Wamana Baru untuk mengisi khutubah Idul Adha beberapa bulan sebelumnya. Beliau juga membawa hewan Qurban sumbangan dari warga pesantren Al-Anshor kepada masyarakat Muallaf.

Pembinaan aqidah tidak hanya dilakukan dengan metode ceramah. Tim Pengabdian IAIN Ambon dan PP Al-Anshor Ambon menerapkan beberapa metode untuk menarik perhatian dan menghindari kebosanan dari peserta pembinaan. Selain itu, diharapkan variasi metode pembinaan diharapkan dapat membuat materi pembinaan lebih mudah dipahami oleh peserta mengingat tingkat pendidikan muallaf kebanyakan tidak bisa baca tulis. Adapun metode-metode pokok pembinaan yang diterapkan yaitu metode informatif, partisipatif, dan eksperiensial dipergunakan untuk mengolah acaraacara pembinaan yang utama.

Dalam praktek pelaksanaan pembinaan, sebelum masuk mengolah acara-acara utama para peserta diberi metode pemanasan yaitu acara pembinaan berupa kegiatan atau permainan yang bertujuan menarik perhatian, membantu untuk sebagai permualaan aktif terlibat pada acara, membantu melepaskan beban mental pada keikutsertaannya dan membantu para peserta terlibat satu sama lain. Metode informatif adalah metode yang menekankan penyampaian informasi dari pembina kepada para peserta. Dalam pelaksanaannya metode dilakukan dengan teknik ceramah, bacaan terarah, dan diskusi panel.

Metode partisipatif partisipatif-eksperisial adalah metode yang dapat melibatkan para peserta. Metode ini pada dasarnya menyangkut permainan peran yang menghubungkan langsung para peserta dengan pengalaman, mempergunakan metode yang mendukung. Maka unsur eksperiensianya tergantung dari keterlibatan peserta pada proses permainann peran yang ada. Penerapan metode ini dilakukan dengan cara meminta peserta menceritakan latar belakang menjadi muallaf dan pengalamannya selama menjadi muallaf. Setiap peserta diminta mendengar dengan seksama dan kalau ada yang ingin memberi komentar atau pendapat maka setiap peserta diberi kesempatan seluas-luasnya.

Metode eksperisial adalah metode yang memberi kemungkinan kepada para peserta untuk "belajar" melalui pengalaman langsung dan nyata. Penerapan metode ini dilakukan dengan mengajak peserta melakukan tadabbur di sekitar desa untuk menyaksikan kemahakuasaan Allah SWT Pencipta alam dan isinya. Tausiyah diberikan sambil berjalanjalan oleh Ust. Abu Imam Rumbara.

\section{Pembinaan Syariah dan Muamalah Muallaf}

Materi pembinaan terkait syariah dan muamalah menjadi penting pula diberikan mengingat sebagai seorang muallaf, mereka menyandang status baru. Tentu saja status baru akan berimplikasi pada peran sosial yang baru di masyarakat. Mereka tidak akan lagi mengikuti ritual ibadah bersama penganut agama sebelumnya. Sebaliknya, mereka akan bertemu dengan banyak orang yang baru dikenalnya. Mereka juga dihadapkan pada kemungkinan orang terdekatnya menolak keputusan yang mereka ambil, terutama orang tua dan keluarga besarnya.

Pembinaan syariah dan muamalah difokuskan pada bimbingan thaharah, bimbingan shalat dan bimbingan penyelenggaraan jenazah. Khusus untuk penyelenggaraan jenazah, bimbingan khusus diberikan kepada perempuan karena terdapat beberapa orang dari pihak laki-laki yang sudah mempelajari perihal penyelenggaraan jenazah lakilaki pada pendidikan muallaf di Ambon.

Khusus untuk interaksi dengan orang tua, Pesantren Al Anshor sebagai mitra kerja Tim 
Pengabdian sangat menekankan pentingnya berbuat baik kepada orang tua, apapun agamanya. Selamanya orang tua adalah orang yang telah melahirkan dan membesarkan hingga dewasa. Karenanya, Islam mewajibkan setiap ummatnya untuk senantiasa berbuat baik kepada orang tua.

\section{a. Bimbingan Thaharah}

Bimbingan thaharah dan ibadah shalat dilakukan pada hari kedua, dimulai pada pukul 08.00 di Masjid Nurul Iman Desa Wamana Baru. Pemateri dan tutor pada program bimbingan ini ialah Ust. $\mathrm{H}$. Ahmad Nurdin, S.Pd dari PP Al-Anshor Ambon dan Dr. H. Subair, M.Si dari IAIN Ambon. Bimbingan diikuti oleh 20 laki-laki dewasa yang seluruhnya adalah muallaf dari desa Wamana Baru.

Bimbingan thaharah dan ibadah shalat menjadi program kedua setelah pembinaan aqidah karena setelah para muallaf itu menyatakan diri menjadi muslim, belum ada program yang mengajari para muallaf tersebut mengerjakan ibadah-ibadah pokok dalam Islam tersebut. Kebanyakan mereka belajar secara autodidak dari buku-buku agama yang dibeli atau sumbangan dari tamu yang datang ke Wamana Baru. Tidak heran jika kebanyakan muallaf tersebut tidak pernah melaksanakan shalat lima waktu meskipun sudah menjadi muslim dalam waktu yang cukup lama.

Program bimbingan dibagi dua tahap yakni program bimbingan thaharah dan program bimbingan ibadah shalat. Bimbingan tharah meliputi mandi junub dan berwudhu sedangkan bimbingan shalat disampaikan seluruh gerakan shalat dari takbiratul ihram sampai salam.

Sebelum memulai materi pertama tentang tata cara mandi junub/janabah, Ust. Ahmad Nurdin menyampaikan beberapa materi terkait thaharah. Dia menyampaikan bahwa Allah itu bersih dan suci. Untuk menemuinya, manusia harus terlebih dahulu bersuci atau disucikan. Allah mencintai sesuatu yang bersih dan suci. Dalam hukum Islam bersuci dan segala seluk beluknya adalah termasuk bagian ilmu dan amalan yang penting terutama karena diantaranya syarat-syarat sholat telah ditetapkan bahwa seseorang yang akan melaksanakan sholat, wajib suci dari hadas dan suci pula badan, pakaian dan tempatnya dari najis. Dalam kehidupan seharihari kita tidak terlepas dari sesuatu (barang) yang kotor dan najis sehingga thaharah dijadikan sebagai alat dan cara bagaimana mensucikan diri sendiri agar sah saat menjalankan ibadah. Suci dari hadas ialah dengan mengerjakan wudlu, mandi dan tayammum. Suci dari najis ialah menghilangkan najis yang ada di badan, tempat dan pakaian.
"Adapun thaharah dalam Islam meliputi menghilangkan najis, berwudhu, mandi janabah, dan tayammum. Alat yang terpenting untuk bersuci ialah air. Jika tidak ada air maka tanah, batu dan sebagainya dijadikan sebagai alat pengganti air. Air yang dapat dipergunakan untuk bersuci ada tujuh macam yaitu Air hujan, Air sungai, Air laut, Air dari mata air, Air sumur, Air salju, dan Air embun".

Selanjutnya dijelaskan tentang cara mandi junub yang wajib dilakukan apabila sebagai salah satu perkara yang sangat penting bagi seorang muslim. Secara khusus dia menjelaskan secara panjang lebar tentang mandi wajib. Kepada peserta disampaikan hukum mandi wajib karena adanya halhal yang mewajibkan mandi yakni hubungan suami istri, mengeluarkan mani, mati, haid, nifas dan melahirkan bagi perempuan. Mandi artinya mengalirkan alir pada apa saja. Menurut pengertian syara' berarti meratakan air yang suci pada seluruh tubuh disertai dengan niat. Pengertian lain ialah mengalirkan air ke seluruh tubuh baik yang berupa kulit, rambut, ataupun kuku.

Ust. Ahmad Nurdin mencontohkan tata cara mandi wajib dengan melakukan simulasi di hadapan peserta. Persoalan mandi wajib sangat diminati oleh peserta karena pengetahuan mereka tentang itu sama sekali tidak ada kecuali mandi itu hanya untuk kebutuhan membersihkan diri belaka.

Berbeda dengan materi bimbingan mandi wajib atau mandi janabah, penjelasan tentang berwudhu dilakukan dengan mengajak peserta langsung mempraktekkannya. Setelah menjelaskan tentang hukum dan hikmah berwudhu, hal-hal yang membatalkan wudhu serta tata cara berwudhu yang sering digunakan oleh umat Muslim sesuai dengan tuntunan Rasulullah SAW, setiap peserta diminta untuk mempraktekkan tata cara berwudhu sampai benar. Dibantu oleh Dr. H. Subair, setiap peserta dibimbing sampai benar-benar diyakini mampu berwudhu dengan cara yang sempurna. Seluruh praktek dilakukan secara simulasi di dalam masjid.

Sebelum peserta melakukan praktek berwudhu dengan menggunakan air yang sesungguhnya, peserta diperkenalkan dan diajari juga cara bersuci menggunakan debu yang dinamakan tayamun. Bimbingan tayamun diberikan atas permintaan Dr. H. Subair dan disetujui oleh peserta. Ust. Ahmad Nurdin membimbing peserta melakukan tayamun yang memang cukup sederhana pelaksanaannya sehingga tidak memakan waktu yang lama. Sambil membimbing tata caranya, dia juga menjelaskan kedudukan tayamun sebagai salah 
satu cara bersuci, sebagai ganti berwudlu atau mandi apabila berhalangan memakai air.

Selanjutnya ketika peserta sudah dianggap memahami dengan benar, mereka diarahkan untuk melakukan praktikum berwudhu dengan menggunakan air yang sesungguhnya. Kegiatan praktikum berwudhu dilakukan di sumur di samping masjid secara bergiliran. Wudhu yang dipraktekkan sekaligus wudhu pertama sebagian besar muallaf yang dilakukan secara benar sepanjang keislaman mereka. Karena sudah memasuki waktu Dzuhur, maka kegiatan pembimbingan thaharah ditutup dan dilanjutkan dengan melaksanakan shalat dzuhur berjamaah di masjid Nurul Iman.

Pada saat yang sama, ibu-ibu dan remaja perempuan mengikuti Pengajian di SMP Negeri Wamana Baru yang berjarak kurang lebih 1 kilometer dari masjid Nurul Iman. Pemateri pada pengajian itu adalah Ustadzah Baiti Renel, M.Si dari IAIN Ambon dan Ummi Imam Rumbara dari Pondok Pesantren Al-Anshor. Jumlah peserta sekitar 30 orang yang mengikuti materi ceramah tentang aqidah Islam dan pokok-pokok muamalah terkait wanita dari pagi sampai siang menjelang shalat Dzuhur

\section{b. Bimbingan Ibadah Shalat Wajib}

Bimbingan ibadah shalat diikuti oleh 42 peserta, terdiri dari 20 orang peserta laki-laki dan 22 orang peserta perempuan. Seluruh anggota tim secara aktif membimbing para muallaf melakukan simulasi shalat wajib yang diajarkan.

Program bimbingan ibadah shalat dimulai dengan penyampaian tausiah oleh Ust. Abu Imam Rumbara yang menyampaikan materi sekitar pentingnya shalat dalam agama Islam. Menurutnya, amal pertama yang dihisab dari seorang hamba di hari kiamat adalah shalat. Dan barangsiapa yang baik (diterima) shalatnya, maka baik (diterima) pula segala amalan yang lain, dan barangsiapa yang rusak (ditolak) shalatnya, maka rusak (ditolak) pula segala amalan lainnya" (HR Thabrani). Karena itu, belajar shalat harus menjadi prioritas utama.

"Setelah seorang muslim memahami thaharah tentang bagaimana cara berwudhu, juga bagaimana cara bersuci, maka berikutnya adalah bagaimana shalat ditegakkan, dan tata cara beserta bacaannya".

Sholat juga merupakan hal yang paling mendasar yang harus dikuasai oleh umat Islam, karena sholat merupakann perwujudan simbol ritual dari umat Islam. Praktek ibadah yang diperkenalkan dan diajarkan oleh pembina kepada muallaf dilakukan secara bertahap dan dengan penuh kesabaran. Meskipun teman mengajarkannya. Dalam tahap pengajaran yang baru diberikan oleh pembina baru ditahap pengenalan gerakan sesekali diselingi dengan bacaan bagi yang sudah cukup akrab dengan bacaan sholat. Kebaikan dan keteguhan para pembina dirasakan positif oleh muallaf.

Materi shalat diberikan tidak hanya dalam bentuk teori, melainkan juga praktik. Sehingga pembimbing dapat langsung membetulkan bila ada praktik yang dianggap masih kurang sempurna. Penyampaikan materi tentang bagaimana cara shalat tidak hanya diberikan teori kepada muallaf, tetapi ustadz juga mencontohkan gerakan-gerakan tersebut, sehingga lebih dapat dipahami.

\section{c. Bimbingan Penyelenggaraan Jenazah}

Bimbingan penyelenggaraan jenazah khusus diberikan kepada peserta perempuan karena beberapa pertimbangan. Pertimbangan pertama karena keterbatasan waktu. Pertimbangan kedua Bimbingan shalat jenazah untuk mayat laki-laki sudah diikuti oleh beberapa orang yang pernah mengikuti pendidikan muallaf di PP Al Anshor Ambon. Termasuk yang sudah mengikuti bimbingan tersebut adalah Gusti Waemese yang disiapkan oleh tim untuk menjadi Imam Desa Wamana Baru. Diharapkan Gusti bisa membimbing beberapa orang laki-laki untuk menyelenggarakan jenazah mengingat penyelenggaraan jenazah merupakan kewajiban yang bersifat kifayah.

Bimbingan penyelenggaraan jenazah dilakukan oleh Ust. Baiti Renel, M.Sos.I dan Andi Fitriyani, M.Si. Pesertanya sekitar 20 orang yang terdiri dari ibu rumah tangga, remaja putri dan guru SD - SMP Wamana Baru. Bimbingan dilakukan secara bergantian antara materi secara teori dan praktek secara langsung. Tim sebelumnya sudah menyiapkan sebuah manekin dan dua set perlengkapan jenazah untuk jenazah laki-laki dan perempuan.

Di awal acara, Ust. Baiti Renel menjelaskan tentang hal-hal yang dikerjakan ketika seseorang sakaratul maut yaitu mentalqin (menuntun) dengan bacaan Laa ilaaha illallah, berdo'a untuknya dan tidak berkata kecuali yang baik. Disampaikan juga tanda-tanda kematian menurut para ulama di antaranya terhentinya nafas, kedua pelipisnya melemas, hidung menjadi lunak, kulit wajahnya menjadi lebih panjang, terpisahnya kedua telapak tangan dari kedua lengannya, kedua kakinya melemas dan terpisah dari kedua mata kaki, tubuh menjadi dingin, dan tanda yang sangat jelas, yaitu adanya perubahan bau pada tubuhnya. Tanda-tanda di atas diketahui dengan tanpa menggunakan alat, 
dan ada tanda lain yang bisa diketahui dengan alatalat kedokteran.

Mengingat bahwa di Desa Wamana terdapat tiga kelompok penganut agama dengan agama adat sebagai mayoritas, maka Ustadzah Baiti Renel menyampaikan bahwa tidak mengapa bagi seorang muslim untuk mendatangi seorang kafir yang dalam keadaan sakaratul maut untuk menawarkan kepadanya agama Islam. Menurut Renel, terdapat sebuah hadits dari Anas Radhiyallahu 'anhu yang diriwayatkan oleh Bukhari-Muslim, beliau berkata: Dahulu ada seorang budak Yahudi yang melayani Rasulullah Shallallahu 'alaihi wa sallam. Ketika dia sakit, maka Rasulullah menjenguknya. Beliau duduk di dekat kepalanya. Kemudian Rasulullah Shallallahu 'alaihi wa sallam bersabda:Masuklah ke dalam agama Islam, maka dia melihat ke arah bapaknya yang berada di sampingnya. Bapaknya berkata: "Taatilah Abul Qasim (ya'ni Muhammad Shallallahu 'alaihi wa sallam)." Maka dia masuk Islam, kemudian Rasulullah keluar, dan Beliau berkata: "Segala puji bagi Allah Yang telah menyelamatkan dia dari neraka."

Selanjutnya Renel menyampaikan tentang hal-hal yang dikerjakan setelah seseorang meninggal dunia yakni pertama, disunnahkan untuk menutup kedua matanya, kedua disunnahkan untuk menutup seluruh tubuhnya, setelah dilepaskan dari pakaiannya yang semula. Ketiga bersegera untuk mengurus jenazahnya. Keempat diperbolehkan untuk menyampaikan kepada orang lain tentang berita kematiannya. Dengan tujuan untuk bersegera mengurusnya, menghadiri jenazahnya dan untuk menyalatkan serta mendo'akannya. Akan tetapi, apabila diumumkan untuk menghitung dan menyebut-nyebut kebaikannya, maka ini termasuk pemberitaan yang dilarang. Kelima, disunnahkan untuk segera menunaikan wasiatnya, karena untuk menyegerakan pahala bagi mayit. Wasiat lebih didahulukan daripada hutang, karena Allah mendahulukannya di dalam Al Qur'an. Keenam, diwajibkan untuk segera dilunasi hutang-hutangnya, baik hutang kepada Allah berupa zakat, haji, nadzar, kaffarah dan lainnya. Atau hutang kepada makhluk, seperti mengembalikan amanah, pinjaman atau yang lainnya. Adapun orang yang tidak meninggalkan harta yang cukup untuk melunasi hutangnya, sedangkan dia mati dalam keadaan bertekad untuk melunasi hutang tersebut, maka Allah yang akan melunasinya. Ketujuh, diperbolehkan untuk membuka dan mencium wajah mayit.

Selanjutnya Ustadzah Baiti Renel menjelaskan tentang tata cara memandikan jenazah.
Memandikan jenazah merupakan perkara yang sangat penting karena hukumnya adalah fardhu kifayah, termasuk mengkafaninya. Apabila telah dikerjakan oleh sebagian kaum muslimin, maka bagi yang lain gugur kewajibannya. Orang yang paling berhak memandikan seorang jenazah, ialah orang yang diberi wasiat untuk mengerjakan hal ini. Seseorang terkadang berwasiat karena ingin dimandikan oleh orang yang bertaqwa, orang yang mengetahui hukum-hukum memandikan jenazah. Setelah orang yang diberi wasiat, orang yang paling berhak untuk memandikan ialah bapaknya, kemudian kakeknya, kemudian kerabat dekat dari ashabahnya (kerabat lelaki). Jika mereka semua sama di dalam hak ini, maka diutamakan orang yang paling mengetahui hukum-hukum mengurus jenazah. Selain itu, diperbolehkan bagi suami atau isteri untuk memandikan pasangannya.

Suasana menjadi haru ketika Ustadzah Baiti menyampaikan bahwa seorang muslim tidak boleh memandikan dan menguburkan seorang kafir dengan mengutip Al-Qur'an Surat At Taubah ayat 84 yang terjemahannya: "Janganlah engkau menyalatkan seorang yang mati di antara mereka selama-lamanya, dan janganlah engkau berdiri di atas kuburnya, sesungguhnya mereka kafir kepada Allah". Hampir seluruh peserta memiliki keluarga dekat yang masih Kafir. Kebanyakan mereka masih memiliki orang tua yang masih menganut agama adat dan atau saudara yang beragama Kristen.

Selanjutnya tata cara dan teknis memandikan jenazah hingga mengkafaninya disampaikan sambil langsung dipraktekkan oleh peserta. Peserta diminta untuk terlibat langsung dengan mengulang-ulang beberapa bagian yang dianggap susah untuk dipahami. Untuk menghindari kesalahan karena lupa baik bacaan maupun caranya, Tim sudah menyiapkan 20 eksamplar Buku Panduan Penyelenggaraan Jenazah yang disusun oleh Tim sebelumnya.

\section{d. Bimbingan Shalat Jenazah}

Bimbingan shalat jenazah dibimbing langsung oleh Ust. Abu Imam Rumbara yang dibantu oleh Ust. H. Ahmad Nurdin. Pelaksanaanya setelah pelaksanaan shalat Ashar di Masjid Nurul Iman dan setelah pelaksanaan bimbingan penyelenggaraan jenazah selesai. Manekin yang sudah dikafani selanjutnya digunakan oleh Ust. Abu Imam sebagai alat peraga dalam praktek shalat jenazah.

Sebelum praktek shalat, terlebih dahulu Ust. Abu Imam menyampaikan beberapa perkara terkait shalat jenazah. Shalat jenazah adalah shalat yang 
dilakukan untuk memberi penghormatan terakhir pada seorang muslim atau muslimah yang sudah meninggal baik itu perempuan atau laki-laki. Anak kecil atau orang tua. Shalat jenazah ada dua macam yaitu salat janazah ghaib dan salat jenazah (hadir). Salat ghaib adalah salat jenazah yang dilakukan tidak dihadapan mayit (jenazahnya berada ditempat lain atau sudah dimakamkan). Salat jenazah hadir atau disebut dengan shalat jenazah saja adalah salat jenazah yang dilakukan di depan mayit dan dilaksanakan sebelum pemakaman. Menshalati jenazah seorang muslim hukumnya fardhu/ wajib kifayah, karena adanya perintah Nabi dalam beberapa hadits.

Dikecualikan dalam hal ini dua jenis jenazah yang tidak wajib dishalati, yaitu anak kecil yang belum baligh dan orang yang gugur $f i$ sabilillah (syahid). Menurut Abu Imam, kedua golongan tersebut kalaupun hendak dishalati maka tidak menjadi masalah bahkan hal ini disyariatkan. Namun pensyariatannya tidaklah wajib.

Selanjutnya Abu Imam menjelaskan bahwa disyariatkan shalat jenazah secara berjamaah sebagaimana shalat lima waktu namun bila mereka mengerjakannya sendiri-sendiri maka telah tertunaikan kewajiban. Semakin banyak jamaah yang menshalati jenazah tersebut, semakin afdhal dan bermanfaat bagi si mayat.

"Bahkan jumlah yang kurang dari 100 pun bermanfaat bagi si mayat, dengan syarat mereka yang menshalatinya itu dari kalangan muwahhidin yaitu orang-orang yang bertauhid dengan tidak mencampurinya dengan kesyirikan sedikit pun".

Disunnahkan makmum yang ikut shalat jenazah tersebut membentuk tiga shaf atau lebih di belakang imam. Ketika jenazah diletakkan untuk dishalati, bila jenazahnya lelaki, imam berdiri di belakangnya pada posisi kepala. Adapun jika jenazahnya wanita maka imam berdiri pada posisi tengahnya.

Setelah diyakini peserta sudah memahami aspek teori dari tatacara shalat jenazah selanjutnya Abu Imam membimbing para peserta untuk mempraktekkan shalat jenazah menggunakan alat peraga. Secara bergantian beberapa peserta yang diproyeksikan untuk menjadi pemuka agama Islam di Wamana Baru diminta untuk memimpin shalat lengkap dengan membaca doa dengan suara keras. Bimbingan shalat jenazah terus dilaksanakan sampai adzan Magrib mau dikumandangkan pertanda waktu Magrib sudah masuk.

\section{e. Pelatihan Guru TPQ}

Pada hari ketiga dilaksanakan kegiatan pelatihan Guru TPQ yang diikuti oleh sekitar 20 orang muallaf. Kebanyakan dari muallaf tersebut masih berusia muda dan terdapat tidak sampai 10 orang yang mampu membaca Al-Qur'an dengan baik dan lancar. Pada dasarnya pelatihan guru TPQ ditujukan untuk menyiapkan sumberdaya manusia yang mampu mengajari anak-anak muslim di Wamana Baru secara mandiri setelah tim meninggalak desa tersebut. Pendidikan al-Qur'an bertujuan untuk meningkatkan kemampuan peserta didik membaca, meningkatkan kemampuan peserta didik menulis, meningkatkan kemampuan peserta didik memahami, dan meninkatkan kemampuan peserta didik mengamalkan kandungan al-Qur'an.

Pemateri pada Pelatihan Guru TPQ adalah Ust. La Isini, S.Pd yang sehari-harinya adalah Kepala Sekolah MA PP Al-Anshor Ambon. Ust. Isini mengajar menggunakan peralatan yang cukup canggih yakni menggunakan in fokus sehingga menarik minta peserta pelatihan untuk belajar.

Pelatihan Guru TPQ dimulai sekitar jam 09.00 bertempat di Masjid Nurul Iman. Kegiatan pelatihan dimulai dengan pengantar dari Ketua Tim, Andi Fitriyani, M.Si. Menurut Andi Fitriyani, pelatihan Guru TPQ dilaksanakan dalam rangka menekan jumlah generasi muda yang buta huruf AlQur'an. Pelatihan guru TPQ bagi muallaf di Desa Wamana Baru diharapkan dapat bermanfaat terutama untuk memberikan informasi dan gambaran sekilas bagi rencana pendirian sebuah taman TPQ, memberikan pedoman dalam mengelola sebuah taman pendidikan dalam bentuk baru dengan metode praktis di bidang pengajaran Al-Qur'an yang memanfaatkan manejemen modern sehingga dengan demikian diharapkan dapat menekan jumlah generasi muda yang buta huruf Al-Qur'an.

Dijelaskan oleh Andi Fitriyani bahwa dalam acara tersebut diberikan materi antara lain Kelembagaan TPA/TPQ; Administrasi pengelolaan lembaga TPQ; Metodologi pengajaran lembaga TPQ meliputi: Metodologi pengajaran Qiro'ati, Metodologi pengajaran Iqro; Metodologi pengajaran Adz Dzikir; Metodologi pengajaran At tartila.

$$
\text { Pada pengantarnya, Ust. Isini }
$$

menyampaikan bahwa TPQ bertujuan menyiapkan terbentuknya generasi Qur'ani, yaitu generasi yang memiliki komitmen terhadap al-Qur'an sebagai sumber perilaku, pijakan hidup dan rujukan segala urusannya. Hal ini ditandai dengan kecintaan yang mendalam terhadap al-Qur'an, mampu dan rajin membacanya, terus menerus mempelajari isi kandungannya, dan memiliki kemauan yang kuat 
untuk mengamalkannya secara kaffah dalam kehidupan sehari-hari. Pendidikan non formal anakanak muslim di tingkat TPQ diharapkan dapat meningkatkan wawasan keislaman dan kemampuan membaca Al-Qur'an para Santri. Melalui pendidikan ini, insya Allah, akan dihasilkan anak-anak muslim yang mau dan mampu berinteraksi dengan alQur'an.

Ust. Isini menjelaskan bahwa dalam proses pendidikan TPQ, guru adalah salah satu faktor penting yang menentukan. Proses pendidikan tidak akan berhasil dengan baik tanpa adanya peran guru/ustadz yang senantiasa memberikan pengajaran setiap hari pada santri-santrinya. Dalam proses pembelajaranpun peran guru masih sangat menentukan daripada metode. Peranan guru sangat penting ini menjadi potensi sangat besar untuk memajukan pendidikan diniyah. Karena guru yang baik akan mendorong terciptanya proses pembelajaran yang baik mulai perencanaan, pelaksanaan dan pengevaluasian.

Kelahiran PP 55/2007 tentang pendidikan agama dan keagamaan telah lama dinantikan oleh penyelenggara pendidikan keagamaan, karena melalui PP tersebut diharapkan dapat membantu peningkatan pendidikan di TPQ. Masalah guru menurut Ust. Isini harus mendapatkan perhatian yang lebih. Karena guru/ustadz di TPQ adalah tenaga relawan yang kerja tanpa pamrih keduniaan hanya mengharapkan reward dari Allah kelak diakhirat. Guru sebagai penopang keberlangsungan pendidikan di TPQ seringkali diabaikan kesejahteraanya dan kepentingan mendasar mereka. Tidak adanya gaji bulanan bagi mereka akan memberikan dampak kekurang seriusan mereka manakala semangat mereka sedang down. Kesulitan anggaran selalu di kemukakan dalam menghadapi masalah ini. Ust. Isini mengingatkan bahwa janji dari Kepala Kantor Kemenag Kabupaten Buru akan memberi insentif bulanan kepada guru TPQ nantinya.

Mengingat bahwa di Desa Wamana Baru belum ada Lembaga Pendidikan Al-Quran berupa TPQ dan berdasarkan amanah Kepala Kantor Kementerian Agama Kabupaten Buru, maka menurut Ust. Isini terdapat 6 persyaratan yang harus dipenuhi untuk mendirikan TPQ yakni; Terdaftar pada Kantor Kementerian Agama Kabupaten/Kota dengan tembusan Dinas Pendidikan Kabupaten/Kota, Memiliki nomor statistik Lembaga Pendidikan Al Qur'an, Memenuhi 8 Standar Nasional Pendidikan, Memiliki tenaga Pendidik/Guru yang profesional/bersertifikat pada
Bidang Ilmu Al Qur'an, Menggunakan salah satu methode belajar Ilmu Al Qur'an yang telah disosialisasikan oleh lembaga Pembina, Memiliki sarana prasarana yang jelas (walaupun di Masjid). Ust. Isini menambahkan bahwa PP Pesantren AlAnshor akan membantu masyarakat muslim Wamana Baru sampai terbentuknya TPQ di Wamana Baru.

Lebih lanjut, Ust. Isini menyampaikan ada 4 standar pengelolaan TPQ, yakni:

- Manajemen kemandirian, kemitraan, partisipasi, keterbukaan dan akuntabilitas serta berbasis masyarakat;

- Menetapkan visi, misi, tujuan agar mampu memberikan inspirasi, motivasi dan kekuatan pada semua pihak yang dirumuskan secara bersama;

- Memiliki izin sesuai denganjenis penyelenggaraan.

- Memiliki sarana dan prasarana belajar Ilmu Al Qur'an

Berbeda dengan lembaga sekolah yang terkenal mahal, TPQ bisa didirikan dengan biaya murah bahkan nyaris tanpa biaya sama sekali. Bisa diselenggarakan di tempat-tempat yang "apa ada"nya, seperti masjid, musholla, atau tempat-tempat lain. Sehingga keberadaannya benar-benar merakyat dan bisa diikuti oleh semua lapisan masyarakat dari kalangan termiskin sekalipun.

Adapun nantinya kalau sudah terbentuk TPQ di Wamana Baru maka diharapkan dapat menyelenggarakan pendidikan utama berisi materimateri yang berperan membentuk generasi muslim yang mengenal baca tulis Al-Qur'an dan taat beribadah, berdo'a dan menegakkan shalat. Pendidikan al-Qur'an merupakan pendidikan dasar yang membekali Santri dalam membaca dan menulis Al-Quran dengan menggunakan modul Metode Iqra. Selain itu, para peserta yang nantinya diharapkan menjadi guru/ustadz-ustadzah bisa membina Santri untuk gemar membaca Al Quraan dan mampu menuliskannya dan membekali Santri dalam berinteraksi dengan Al Quraan secara lebih intensif di kemudian hari.

Selain itu, nantinya lembaga pendidikan TPQ yang terbentuk juga memberikan pendidikan ibadah yang merupakan pendidikan untuk membentuk pribadi muslim yang taat beribadah. Pendidikan ibadah juga meliputi pembinaan Santri untuk mampu menghafal bacaan do'a dan ayat-ayat Al-Qur'an, taat beribadah melaksanakan shalat dan hafal beberapa do'a sehari-hari serta surat-surat pendek dalam al-Qur'an. Dan yang terpenting, 
melatih anak untuk melaksanakan ibadah shalat fardlu dari sejak usia dini.

Selain pendidikan utama, menurut Isini, TPQ juga perlu melaksanakan Pendidikan Pendukung yang dimaksudkan untuk mengembangkan potensi diri dan kemampuan beraktivitas sosial. Anak dibina untuk mampu mengekspresikan bakat dan minatnya dalam aktivitas ekstra kurikuler, seremonial dan event perlombaan. Kegiatan ekstra kurikuler bertujuan untuk membina anak untuk berkemampuan seni Islami dalam berbagai kegiatan ekstra kurikuler yang menjadi pilihan para anak. Adapun ekstra kurikuler tersebut antara lain menggambar dan mewarnai, Kaligrafi, Membaca Puisi, Qosidah, Drama, Seni Tilawah, Seni Rebana dan lain sebagainya.

Kegiatan seremonial berupa peringatan hari besar Islam bertujuan untuk membina anak untuk berpartisipasi dalam berbagai kegiatan seremoni dalam rangka perayaan/peringatan hari-hari besar umat Islam. Adapun aktivitas seremonial tersebut antara lain Perayaan Tahun Baru Hijriyyah, Peringatan Maulid Nabi Muhammad s.a.w., Peringatan Isra' Mi'raj, Kegiatan Bulan Ramadlan (Nuzulul Qur'an, Tadarus, dll), Halal Bi Halal dan lain sebagainya.

Kegiatan berupa Event perlombaan bertujuan untuk membina anak untuk berprestasi dalam berbagai kegiatan lomba tingkat TPQ baik yang diselenggarakan internal maupun eksternal. Adapun event perlombaan tersebut antara lain Festifal Anak Shalih, Musbaqah Tilawatil Quraan untuk TPQ, Lomba melukis dan mewarnai, Lomba kaligrafi, Lomba 17 Agustusan dan lain sebagainya.

\section{f. Pembentukan Majelis Taklim}

Pembentukan Majelis Taklim dilakukan pada pertemuan yang dilaksanakan setelah pelaksanaan Shalat Jumat di Masjid Nurul Iman. Pertemuan dipimpin langsung oleh Ust. Abu Imam Rumbara dengan harapan PP Al-Anshor nantinya yang akan melakukan pembinaan secara berkesinambungan setelah Tim kembali ke Ambon. Dalam pengantarnya, Ust. Abu Imam menjelaskan bahwa majelis taklim adalah salah satu lembaga pendidikan diniyah non formal yang bertujuan meningkatkan keimanan dan ketakwaan kepada Allah SWT dan akhlak mulia bagi jamaahnya, serta mewujudkan rahmat bagi alam semesta. Dalam prakteknya, majelis taklim merupakan tempat pangajaran atau pendidikan agama Islam yang paling fleksibal dan tidak terikat oleh waktu. Majelis taklim bersifat terbuka terhadap segla usia, lapisan atau strata sosial, dan jenis kelamin. Waktu penyelenggaraannya pun tidak terikat, bisa pagi, siang, sore, atau malam . tempat pengajarannya pun bisa dilakukan di rumah, masjid, mushalla, halaman, dan sebagainya. Selain itu majelis taklim memiliki dua fungsi sekaligus, yaitu sebagai lembaga dakwah dan lembaga pendidikan non-formal. Fleksibelitas majelis taklim inilah yang menjadi kekuatan sehingga mampu bertahan dan merupakan lembaga pendidikan Islam yang paling dekat dengan masyarakat. Majelis taklim juga merupakan wahana interaksi dan komunikasi yang kuat antara masyarakat awam dengan para mualim, dan antara sesama anggot jamaah majelis taklim tanpa dibatasi oleh tempat dan waktu. Dengan demikian majelis taklim menjadi lembaga pendidikan keagamaan alternative bagi mereka yang tidak memiliki cukup tenaga, waktu, dan kesempatan menimba ilmu agama dijulur pendidikan formal. Inilah yang menjadi alasan tim pengabdian IAIN Ambon membentuk Majelis Taklim pada komunitas muallaf di Wamana Baru.

Dari hasil pertemuan disepakati nama Majelis Taklim yang akan dibentuk diberi nama Majelis Taklim Nurul Hikmah. Pertemuan juga berhasil memilih pengurus yang terdiri dari Ketua, Wakil Ketua, Sekretaris dan Bendahara. Disepakati juga bahwa semua anggota Tim Pengabdian IAIN Ambon - PP Al-Anshor menjadi anggota Dewan Pembina di mana Ust. Abu Imam Rumbara sebagai Ketua Dewan Pembinanya. Diharapkan dalam waktu kurang dari sebulan pengurus majelis taklim Nurul Hikmah sudah bisa menyusun rencana program dan melaksanakan pengajian. Ust. Abu Imam Rumbara menunjuk Ust. Abdul Rumalutur yang menetap di Wamana Baru untuk membantu pengurus menyusun program dan menjadi penghubung antara Pengurus dengan Pondok Pesantren Al-Anshor di Ambon.

Setelah seluruh komposisi pengurus terbentuk, Ust. Abu Imam selanjutnya meminta kesediaan Dr. H. Subair, M.Si untuk meresmikan majelis taklim yang baru saja terbentuk. Dalam sambutannya, Dr. Subair dengan nada haru menyampaikan apresiasinya kepada para muallaf yang begitu bersemangat belajar Islam meskipun dengan keadaan yang begitu terbelakang tanpa pembinaan yang memadai. Ketika orang Islam lainnya meninggalkan shalat karena lalai maka di Wamana Baru para Muallaf justru baru belajar shalat dalam keadaan kekurangan bimbingan. Belum lagi persoalan lain berupa penentangan dari keluarga dekat yang belum mendapat hidayah. Dr. Subair bahkan sempat mengeluarkan air mata ketika 
menceritakan kisah seorang muallaf muda, Gusti Waemese, yang selalu menangis karena membayangkan orang tuanya akan menjadi penghuni neraka apabila ia tidak berhasil mengislamkan keduanya.

Dr. Subair pada akhir sambutannya sebelum meresmikan pembentukan majelis Taklim Nurul Hikmah meminta kepada semua anggota tim untuk memberi bantuan modal awal bagi dana awal operasional Majelis Taklim atas bisikan dari Ust. Abu Imam. Seketika terkumpul sekitar Rp. 2.000.000 sebagai modal awal.

Sebelum pembacaan doa penutup, Ustadzah Baiti Renel menyampaikan apresiasi yang sama kepada semangat belajar Islam yang sangat tinggi dari para muallaf di Wamana Baru. Ustadzah Baiti yang merupakan pembina beberapa Majelis Taklim di Kota Ambon berjanji bersedia datang ke Wamana Baru kapan pun dibutuhkan oleh Pengurus majelis taklim. Dia berjanji tidak perlu dibayar dan tidak perlu dipikirkan soal transportasinya untuk ke Wamana Baru.

Pertemuan pembentukan majelis taklim selesai menjelang masuknya waktu Ashar. Pertemuan ditutup dengan pembacaan doa bersama yang dipimpin oleh Ust. Abu Imam Rumbara.

\section{g. Pembentukan dan Pembinaan Pegawai Syara'}

Dakwah pada level desa biasanya secara dimotori oleh para imam dan takmir masjid yang secara struktural dipilih secara langsung oleh umat dan biasanya disebut dengan Pegawai Syara'. Pegawai Syara' inilah sesungguhnya pelaksana lapangan yang setiap saat bersinggungan dengan umat. Karena itu, wajah kemajuan keberagamaan umat di level desa sangat tergantung sejauh mana kualitas personal dan manajerial para Pegawai Syara' tersebut.

Mengingat eksistensi Pegawai Syara' yang demikian urgennya maka meningkatkan kualitas baik secara personal maupun manajerial mereka sama halnya dengan peningkatan kualitas kehidupan keagamaan di tengah masyarakat di desa. Kemampuan personal yang harus dimiliki Pegawai Syara' meliputi pengetahuan keagamaan, sosial, dan budaya. Sementara penguasaan manajerial meliputi bagaimana cara mengelola dan memanfaatkan sinergis potensi yang ada di tengah masyarakat untuk digunakan secara optimal bagi pelaksanaan dakwah secara lebih luas sehingga tercipta suasana masyarakat yang tumbuh dan berkembang dalam nilai-nilai dan tatanan masyarakat Islam.
Pembinaan pegawai syara' pada dasarnya inklud ke dalam seluruh kegiatan pembinaan keagamaan yang dilakukan di Desa Wamana Baru. Tetapi meengingat banyaknya masalah keagamaan yang terjadi sebagai akibat dari tidak adanya pegawai syara' di Wamana Baru sehingga secara khusus diagendakan kegiatan pembentukan dan pembinaan pegawai syara'. Maksud pembentukan dan pembinaan institusi Pegawai Syara' dalam dalam rangka meningkatkan penyelenggaraan ibadah serta mendorong pelaksanaan kegiatan pada masjid di Wamana Baru. Perangkat syara' dibentuk dalam rangka usaha memberi pelayanan kepada masyarakat di bidang keagamaan. Perangkat Syara' juga dibentuk dalam rangka memberikan bimbingan dalam kehidupan beragama terhadap 45 kepala keluarga Islam dan sekitar 137 penduduk muslim di Desa Wamana Baru. Dengan demikian, Pegawai Syarak tidaklah semata untuk penyelenggaraan ibadah ritual shalat semata, melainkan lebih jauh menjalankan fungsi pembinaan keagamaan bagi masyarakat muallaf.

Secara khusus pelatihan Pegawai Syara' di Desa ini bertujuan untuk memberikan pencerahan terhadap Tupoksi dalam pelaksanaan Ibadah, Ibadah Sosial kemasyaakatan, sehingga dapat berfungsi sebagai khotib dan imam dalam sholat memperbaiki/membetulkan bacaan ayat-ayat dalam sholat yang belum sempurna menurut ilmu tajwid, tatacara dan tajwid sholat. Materi Pelatihan berupa kebijakan Pemerintah Kabupaten Buru di bidang Agama, Fungsi Imam dan Khotib, fungsi peranan imam dan khotif, Tupoksi dan tanggung jawab pegawai syara', praktek dan hapalan surat pendek dalam sholat. tanggung jawab Pegawai syara dalam kehidupan kemasyarakatan, serta Maqaranatul Mazahib Fil Ibadah. Metode pelatihan berupa ceramah dan tanya jawab serta praktek setiap peserta guna lebih lebih memantapkan ilmu pengetahuan ibadah bagi Imam dan khotib dan perangkat masjid lainnya.

\section{KESIMPULAN}

Persoalan muallaf di Wamana Baru tidak hanya sebatas masalah aqidah, ibadah dan muamalah belaka juga terkait dengan masalah kelembagaan yakni tidak adanya perangkat syara' yang melayani dan memenuhi kebutuhan masyarakat muallaf. Sebagai akibatnya, beberapa ibadah dan amalan pokok seperti shalat Jumat, penyelenggaraan jenazah hingga kepada pendidikan Islam tidak pernah dilaksanakan di Desa Wamana Baru. Bahkan hasil temuan yang sangat menyentuh hati adalah 
bercampurnya keyakinan dan praktek agama terdahulu, terutama dalam perkawinan dan khitan bagi laki-laki. Hampir semua muallaf yang ada Wamana Baru belum menikah secara hukum agama melainkan menganggap cukup dengan nikah secara adat karena adat adalah puncak tertinggi dalam tata hukum mereka.

Terdapat sekitar 47 keluarga muallaf belum menikah secara Islam dan karenanya beum juga memiliki legalitas resmi dari negara berupa Surat Nikah. Sebagai solusi sementara, pasangan tersebut seharusnya diusahakan untuk mengikuti nikah ulang (tajdidun nikah) sebagaimana ditawarkan oleh Kepala Kantor Kementerian Agama Kabupaten Buru. Pernikahan ulang sangat penting untuk dilakukan selain karena terkait dengan sah tidaknya perkawinan setiap pasangan, juga bertujuan untuk melindungi keluarga para muallaf tersebut, sehingga keturunannya kedepan bisa mendapatkan jaminan pelayanan dari pemerintah, setelah mengantongi buku nikah. Seperti halnya akta kelahiran anak nantinya bisa diurus setelah mengantongi surat nikah.

Pernikahan ulang bertujuan untuk melindungi keluarga, terutama bagi istri. Dengan tercatatnya pernikahan di Kementrian agama, keturunan dari suatu keluarga ada kejelasan, sehingga mudah dalam mendapatkan surat administrasi kependudukan, dan kita berhak mendapatkan pelayanan pemerintah.

Solusi jangka panjangnya adalah pembentukan dan pembinaan perangkat syara' yang pada gilirannya menjadi lembaga yang akan memenuhi kebutuhan keagamaan masyarakat. Pembinaan perangkat syara' sebagai bagian dari pembinaan keagamaan di desa didasari dari peran perangkat syara' di desa tersebut bukan sekedar menjadi imam masjid saja. Tapi juga mengetahui tentang ilmu pertanian, ilmu ekonomi, sehingga apapun yang menjadi masalah di masyarakat ia bisa ikut memecahkannya. Dilihat dari peran dan fungsi imam desa, memang cukup berat. Seringkali mereka multifungsi: menjadi imam shalat rawatib, mengurus fadhu kifayah, juru damai jika ada konflik dalam masyarakat, tokoh adat, amil zakat, nazir waqaf, hingga menjadi penasihat dan menyelesaikan masalah-masalah kemasyarakatan. Imam desa juga orang yang ikut bertanggungjawab terhadap kepemimpinan desa, selain kepala desa dan kepala Soa.

Pada akhirnya, tidaklah lengkap pendampingan dan pembinaan muallaf tanpa memberdayakan ekonomi mereka karena pada dasarnya kefakiran dekat kepada kekafiran. Sehingga rencana program selanjutnya ialah program pemberdayaan sosial dan ekonomi.

\section{DAFTAR PUSTAKA}

Al-Qur'an dan Terjemahnya. 1989. Edisi Baru Revisi, Semarang: CV. Toha Putra SemaranG.

Ahmad, A. 1995. Dakwah sebagai Ilmu, Yokyakarta: Fakultas Dakwah IAIN Sunan Kalijaga.

Al-Albāny, M.N. 2007. Shahīh at-Targhīb wa atTarhīb. Jakarta: Pustaka Sahifa.

Anitasari, D. dkk. 2010. Perempuan dan Majelis Taklim: Membicarakan Isu Privat Melalui Ruang Publik Agama. Bandung: Research Repport Rahima April 2010.

Anshari, E.S. 1976. Pokok-pokok Pikiran tentang Islam, Jakarta: Interprises.

Aziz, JA. 2005. Fiqh ad-Da'wah : Studi atas Berbagai Prinsip dan Kaidah yang Harus Dijadikan Acuan dalam Dakwah Islamiyah, Abdussalam Masykur, Solo: Intermedia.

Chisaan, C. 2010. "Mualaf" dalam Nurcholis Setyawan, dkk. Meniti Kalam Kerukunan, Beberapa Istilah Kunci dalam Islam dan Kristen, PT BPK Gunung Mulia: Jakarta.

Darmawan, A. 2002. Metodologi Ilmu Dakwah, Yogyakarta: Kurnia Kalam Semesta.

Denzin, N.K. \& Y.S. Lincoln (eds.). 2000. Handbook of Qualitative Research (Second Edition), Thousand Oaks: Sage Pul. Inc.

Al-Habsyi, Muhammad Bagir. 1999. Fiqih Praktis, menurut Alquran, As-Sunnah dan pendapat para ulama, Bandung:Mizan.

Margaretha, 2009. Perjalanan Panjang Menggapai Iman; memoar pergolakan ba- tin seorang pemeluk agama tentang iman yang diyakininya, PT Pus taka Insan Madani: Yogyakarta.

Moleong, L.J. 2012. Metodologi Penelitian Kualitatif, PT. Remaja Rosda karya: Bandung.

Mubarok, A. 1999. Psikologi Dakwah, Jakarta: Pustaka Firdaus.

Mughniyah, M.J. 2005. Al-.Fiqh 'ala al-madzahib al-khamsah, terj. Masykur A.B et.all, Fiqih Lima Madzhab, Jakarta, Lestari Basritama.

Muslim ibn al-Hajjâj, Shahih Muslim, juz IV, Beirut: Dar Ihyâ at-Turas al-'Arabî, tth. 
Noorkamilah, 2014. Pembinaan Muallaf; Belajar dari Yayasan Ukhuwah Muallaf (Yaumu) Yogyakarta. Jurnal PMI Vol. XII. No. 1, September 2014, 1-20.

Sabiq, S. 2006. Fiqhus sunnah, terj. Nor Hasanuddin dkk, Jakarta: Pena Pundi Aksara.

Siregar, I. dan Shofiuddin, M. 2003. Pendidikan Agama Luar Sekolah (Studi Tentang Majelis Taklim). Jakarta: Puslitbang Pendidikan Agama dan Keagamaan Badan Litbang Agama dan Diklat Keagamaan Departemen Agama RI.

Suisyanto, dkk. 2011. Pembinaan Muallaf, Dirjen Kemenag dan Kelompok Studi al Fikroh: Yogyakarta.

Sumodiningrat, G. 1999. Pemberdayaan Masyarakat dan Jaring Pengaman Sosial. Jakarta: Gramedia Pustaka Utama.

Syamsuddin, Subair, Andi Fitriyani, Darma. 2015. Pemberdayaan Komunitas Muallaf di Kecamatan Siwalalat Kab. Seram Bagian Timur, Maluku. Yogyakarta: Direktorat Jenderal Pendidikan Islam Kementerian Agama RI dan Aynat.

Tasmara, T. 1997. Komunikasi Dakwah, Jakarta: Gaya Media Pratama.

Winter, R. 1989. Learning From Experience: Principles and Practice in Action-Research, Philadelphia: The Falmer Press.

Qardawy, Y. 2004. Fiqh Zakat, terj. Salman Harun et.all, Hukum Zakat: Studi Komparatif mengenai Status dan Filsafat Zakat Berdasarkan Quran dan Hadis, Bogor, Pustaka Litera AntarNusa. 